\title{
A Rare Cause of Brain Abscess: Enterococcus raffinosus
}

\section{Nadir Görülen Bir Beyin Apsesi Etkeni: Enterococcus raffinosus}

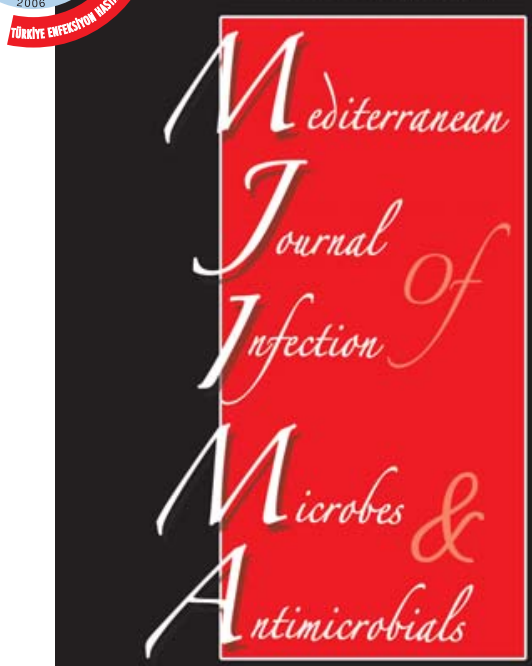

Hava YILMAZ', Esmeray MUTLU YILMAZ², Mustafa SÜNBÜL ${ }^{1}$

${ }^{1}$ Department of Infectious Diseases and Clinical Microbiology, Faculty of Medicine, Ondokuz Mayis University, Samsun, Turkey

${ }^{1}$ Ondokuz Mayıs Üniversitesi Tıp Fakültesi, Enfeksiyon Hastalıkları ve Klinik Mikrobiyoloji Anabilim Dalı, Samsun, Türkiye

2 Department of Infectious Diseases and Clinical Microbiology, Samsun Mehmet Aydin Training and Research Hospital,

Samsun, Turkey

${ }^{2}$ Samsun Mehmet Aydın Eğitim ve Araştırma Hastanesi, Enfeksiyon Hastalıkları ve Klinik Mikrobiyoloji Kliniği, Samsun, Türkiye

\section{ABSTRACT}

In this paper, a case of brain abscess caused by Enterococcus raffinosus in a patient with history of chronic otitis mediais presented. A male patient applied to the emergency unit with severe headache and ear pain. His examination revealed otitis media and perforation of the left ear tympanic membrane. Brain tomography showed an abscess causing a midline shift to theright side in the left temporoparietal lobe. E. raffinosus, a rare pathogen, was identified in the material removed during surgery.

Key words: Enterococcus raffinosus, chronic otitis media, brain abscess

Received: 09.10.2014 • Accepted: 22.12.2014 • Published: 31.12.2014

\section{ÖZET}

Bu yazıda kronik otitis media öyküsü olan hastada gelişen Enterococcus raffinosus'un etken olduğu beyin apsesi olgusu sunulmuştur. Şiddetli baş ve kulak ağrısı olan erkek hasta acil servise başvurdu. Muayenesinde sol kulak zarında perforasyon ve otitis media tespit edildi. Beyin tomografisinde sol temporopariyetal lobda şift etkisi de yapan apse görüldü. Operasyonda alınan örnekten nadir bir patojen olan $E$. raffinosus identifiye edildi.

Anahtar kelimeler: Enterococcus raffinosus, kronik otitis media, beyin apsesi

Geliș Tarihi: 09.10.2014 • Kabul Ediliș Tarihi: 22.12.2014 • Yayınlanma Tarihi: 31.12.2014 


\section{INTRODUCTION}

Brain abscess is a serious neurologic condition with a $13.4 \%$ mortality rate ${ }^{[1]}$. Usually, aerobe and anaerobe microorganisms jointly cause this condition $^{[2]}$. Brain abscess associated with enterococci is quite a rare condition. Untreated or chronic autogenic infections may result in brain abscesses ${ }^{[2-4]}$. Brain abscess secondary to chronic otitis media may develop due to adjacency. In this papera case of brain abscess, believed to have developed secondary to otitis media and for which Enterococcus raffinosus was isolated as the causal factor, is presented.

\section{CASE}

A 31-year-old male patient presented to our healthcare center with fever, severe headache and left ear pain, nausea, and vomiting persisting for the past eight days. Following brain tomography demonstrating a brain abscess, the patient was referred to the Emergency Department of our University. His general condition was good at the Emergency Department. He was conscious but his orientation and cooperation was weak. His temperature was $36.4^{\circ} \mathrm{C}$, pulse rate 82 beats/minute, and blood pressure 110/60 $\mathrm{mmHg}$. There was pain in his left ear but no discharge. Other systemic examinations were normal. He had a history of intravenous illicit drug use and addiction, and intermittent discharge from the left ear, for which he had not received any drug treatment.
Laboratory findings were as follows: $\mathrm{Hb} 9.9 \mathrm{~g} / \mathrm{dL}$; leukocyte $14.600 / \mathrm{mm}^{3}$ (neutrophil rate, $81 \%$ and lymphocyte rate, $13 \%$ ); erythrocyte sedimentation rate 68 $\mathrm{mm} /$ hour; and C-reactive protein $40 \mathrm{mg} / \mathrm{L}$. Computerized tomography (CT) and magnetic resonance imaging (MRI) demonstrated a smooth, thin-walled mass lesion sized $54 \times 44 \times 34 \mathrm{~mm}$, consistent with an abscess at the left temporoparietal region with subcortical localization, which caused a shift and had findings of air (Figures 1,2). He was admitted to the brain surgery clinic and an empirical ceftriaxone $4 \mathrm{~g}$ per day and metronidazole $2 \mathrm{~g}$ per day were initiated intravenously (IV). A brown, putrid abscess material (25 cc) was drawn out by suction. E. raffinosus was identified from direct microbiological culture of the abscess material. The identification of $E$. raffinosus was made by VITEK 2 system (bioMérieux, France) with $99 \%$ certainty and repeated by Phoenix system (BDP, USA). No proliferation was observed in the anaerobe culture. The strain was susceptible to ampicillin, vancomycin, teicoplanin, linezolid, and high level gentamycin but resistant to penicillin by VITEK 2. Ceftriaxone treatment was switched to ampicillin (12 g per day IV), and the patient was transferred to infectious diseases clinic. Since aerobe and anaerobe pathogens usually coexist in brain abscesses, metronidazole ( $2 \mathrm{~g}$ per day IV) was continued for potential anaerobe factors ${ }^{[1]}$. The patient was negative for human immunodeficiency virus (HIV).

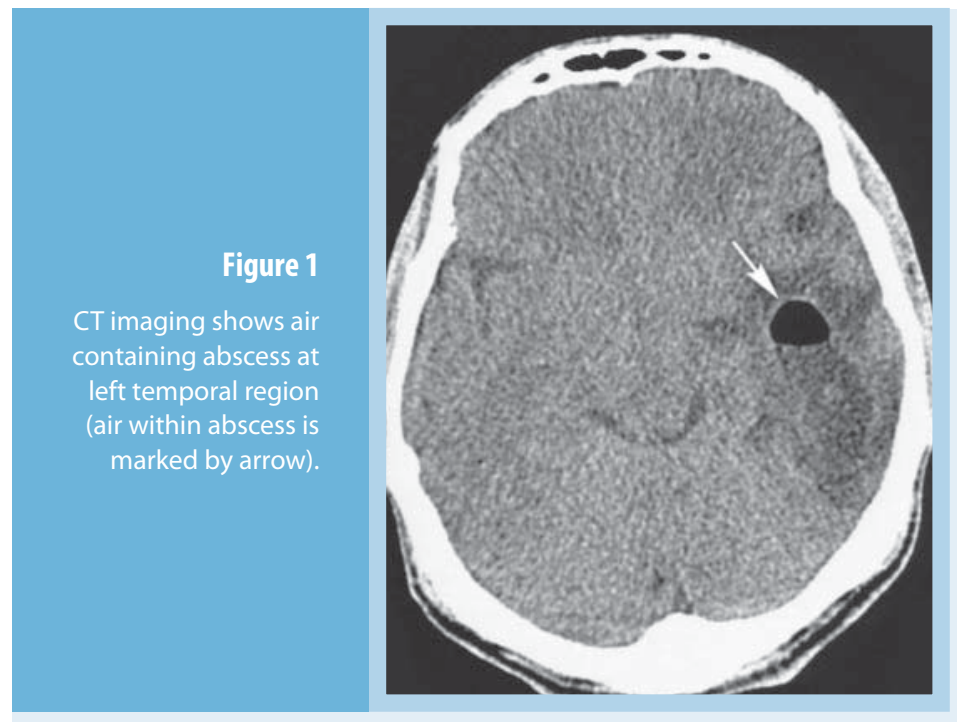




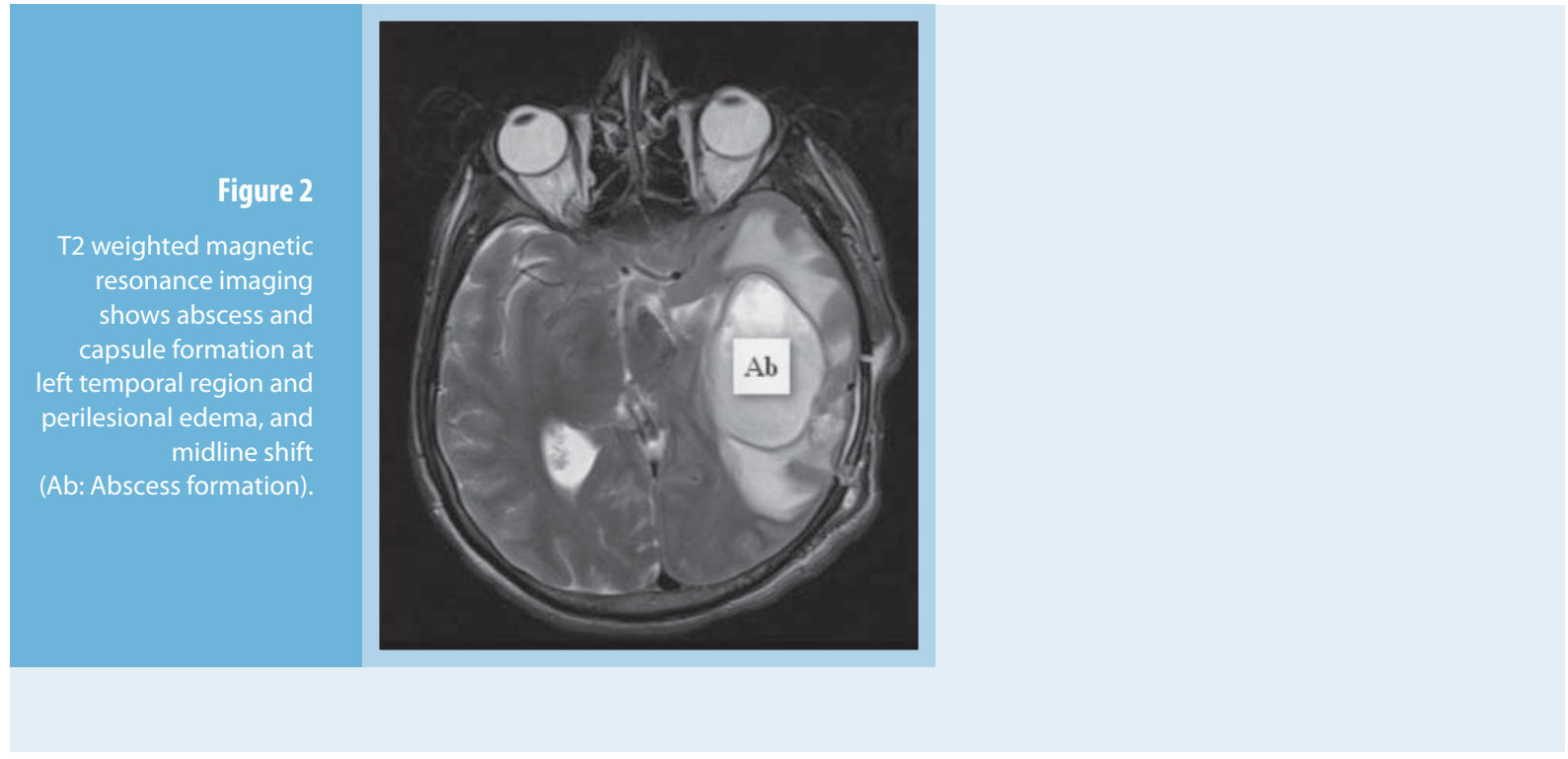

A second abscess drainage was performed ten days later since expected reduction in the abscess size was not achieved. There was no growth in the culture of second drainage material.

A follow-up brain MRI after six-weeks of iv treatmentshowed a regression in the lesion to $24 \times 19 \mathrm{~mm}$, and the shifting effect of the mass disappeared. Examination by the otolaryngology department revealed left ear tympanic membrane perforation and chronic otitis media with mastoiditis. Surgical intervention was scheduled for the patient. Although antibiotic therapy continued, he left the hospital at his own request.

\section{DISCUSSION}

Untreated or chronic ear infections may lead to intracranial infections, including brain abscess ${ }^{[5]}$. A brain abscess is often caused by several aerobe and anaerobe microorganisms with only a few reports describing brains abscess associated with enterococci. Kurien et al. described only one brain abscess caused by enterococcus bacteria among 153 cases of brain abscess in India in $1993^{[6]}$. Sanovane et al. have reported the development of Enterococcus spp. brain abscess secondary to chronic otitis media in a patient with cerebellopontine angle tumor ${ }^{[5,6]}$.

Enterococcus spp. mainly inhabit the gastrointestinal system in humans. Less frequently, they occupy the genitourinary tract and the oral cavity. Clinically, they most commonly cause urinary system infections.
They may be the casual factor of pelvic abscess, neonatal meningitis and sepsis, empyema, endophthalmitis, sinusitis, and chronic otitis media. The most frequently isolated species is Enterococcus faecalis. The second species most commonly isolated from clinical samples is Enterococcus faecium, followed by rare cases of Enterococcus casseliflavus and E. raffinosus ${ }^{[1,7,8]}$. The causative agent of otitis media could not be isolated in our patient since he had no ear discharge. Bone-tissue culture was scheduled after mastoiditis culture; however, the patient refused to undergo this procedure. We believe that patient's chronic otitis media predisposed the adjacent temporal zone to brain abscess. Previous studies have reported otitis media to be the most common predisposing factor $(38.6 \%)$ for brain abscess, and the temporal lobe to be the most commonly affected organ ${ }^{[1,9]}$.

In contrast to antibiotic resistance, which is common in E. faecalis and E. faecium, other enterococci are more sensitive to beta-lactams and aminoglycosides. Superiority of other beta-lactams to ampicillin has not been demonstrated in enterococci infections, where the infection is not polymicrobial ${ }^{[1,2]}$. Therefore, ampicillin was prescribed to the patient.

Enterococci may be observed, though rarely, as the cause of brain abscesses in patients with chronic otitis media. This should be taken into consideration when planning empirical antibiotic treatment. 


\section{REFERENCES}

1. Nathoo N, Nadvi SS, Narotam PK, et al. Brain abscess: management and outcome analysis of a computed tomography era experience with 973 patients. World Neurosurg 2011; 75: 716-26.

2. Tunkel AR. Brain abscess. In: Mandell GL, Bennett JE, Dolin $R$ (eds). Principles and Practice of Infectious Diseases. $7^{\text {th }}$ ed. Philadelphia: Churchill Livingstone, 2010: 1265-78.

3. Mohanty S, Dhawan B, Kapil A, et al. Brain abscess due to Enterococcus avium. Am J Med Sci 2005; 329: 161-2.

4. Mohanty S, Kapil A, Das BK, et al. Enterococcus avium cerebellar abscess. Neurol India 2006; 54 : 108-9.

5. Sonavane A, Baradkar V, Kumar S. Enterococcal cerebellopontine angle abscess in a 12-year-old female. J Glob Infect Dis 2010; 2: 67-9.

6. Kurien M, Job A, Mathew J, et al. Otogenic intracranial abscess: concurrent craniotomy and mastoi- dectomy-changing trends in a developing country. Arch Otolaryngol Head Neck Surg 1998; 124 : 1353-6.

7. Sandoe JA, Witherden IR, Settle C. Vertebral osteomyelitis caused by Enterococcus raffinosus. J Clin Microbiol 2001; 39: 1678-9.

8. Savini V, Manna A, D'Antonio F, et al. First report of vaginal infection caused by Enterococcus raffinosus. J Med Microbiol 2008; 57: 672-3.

9. Pehlivan Y, Toy MA, Karaoglan I, et al. Enterococcus avium cerebral abscess. Intern Med 2007; 46: 1280.

Yazışma Adresi /Address for Correspondence

Dr. Esmeray MUTLU YILMAZ

Samsun Mehmet Aydın Eğitim ve Araştırma Hastanesi

Enfeksiyon Hastalıkları ve Klinik Mikrobiyoloji Kliniği

Samsun/Türkiye

E-posta: emutlu55@gmail.com 